\title{
Biblical principles towards a pastoral strategy for poverty alleviation amongst the youth in Uganda
}

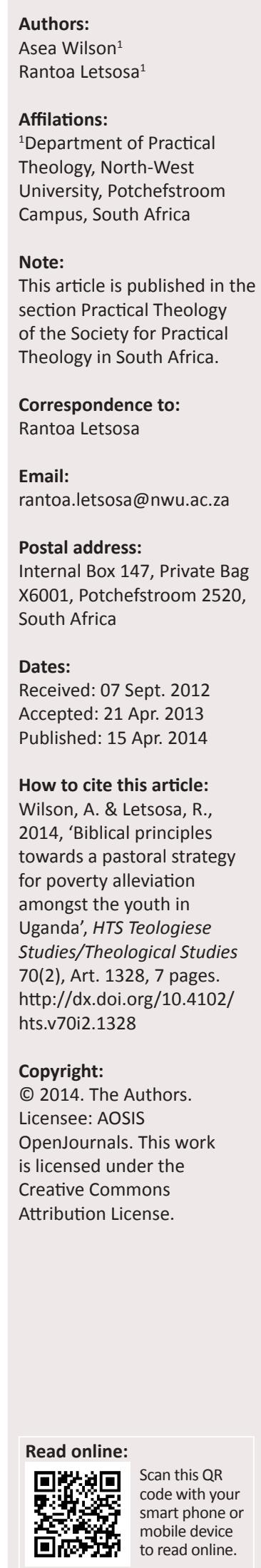

Over centuries, many churches in Uganda have failed to do justice to the gospel to the materially and socially robbed. Their preoccupation has been with the gospel to the sinners. But the salvation of sinners and the care for the materially and socially deprived are part of one and the same gospel. In other words, these churches could not handle the two gospels that are found in the Bible: the salvation of the sinners and care for the physical needs of the poor. It has a gospel for the 'sinning', but no gospel for the 'sinned against'. The church in Uganda must now become involved in the process of mutual commitment to freedom, justice and care for the disadvantaged. It must develop a complete theology of the divine grace for sinners as well as the gospel for the materially and socially disadvantaged. Moreover, however, eradicating material poverty is not simply a matter of making more and better provisions available, but of expanding actual participation so that young people might fulfil their own roles in the whole society to which they belong. An attempt was made to define poverty and to discuss the characteristics of poverty through the exposition of the weak points of both the church and the government that were constructed by means of a literature study as well as qualitative interviews in contrast to the biblical strength that was determined through an exegetical study of texts that specifically dealt with issues of poverty. The views of churches with regard to poverty were taken into consideration. Last but not least, a possible means was developed that could be utilised to break down the persistent poverty amongst the youth in Uganda.

\section{Introduction}

This article is about poverty amongst young people in Uganda, about their confusion between the biblical truth concerning prosperity and material wealth with a prosperity gospel proclaimed by a number of churches today. Whilst some churches have a balance between the spiritual and physical aspects of life, others have spiritualised divine grace too easily by failing to care for the physical needs of the poor. Hence, the spirituality of many young people has not been upheld, but stolen from them, they have little hope and they have learned to mistrust the whole church. God to them is nameless and is seldom seen as the liberator. The church has lost a number of young people whom Christ loves most. Hence the question: What role can the church play to give poor young people in Uganda a vision and inspiration so as to empower them to ameliorate their circumstances and bring about liberation from their situation of poverty? It should be born in mind that preaching and development must be part of a process of poverty alleviation by the church. The church must now become involved in the process of mutual commitment to freedom, justice and care for the disadvantaged. It must develop a complete theology of divine grace for sinners as well as the gospel for the materially and socially disadvantaged.

Moreover, however, eradicating material poverty is not simply a matter of making available more and better provisions, but also of expanding actual participation so that the young people might fulfil their own roles in the whole of the society to which they belong. Hence, Tumusiime (1998) explores the implications of an old Chinese saying to emphasise the difference in approach:

$[R]$ ather than providing hand-outs that leave the young people in Uganda mired in helplessness and an undignified state in which they might find themselves, the ministers must learn from them, start with what they know, build on what the young people have [e.g. business or the church can initiate incomegenerating projects and employ them or link up those with qualifications for job opportunities.] (p. 52)

A previous article has been published that focused on principles for poverty alleviation amongst the youth in Uganda. This article looks spefically at biblical principles that may be used as a pastoral strategy for poverty alleviation amongst the youth in Uganda. Whilst the previous article focused more on meta-theoretical issues and empirical results, this article focusses more on biblical teachings on poverty alleviation, since many young people are devoted church members and need answers from the church to a large extent and not simply from society.

\section{Concept of poverty and the youth}

Recent anthropological and sociological studies have shown that the word poor refers to more than merely an economic concept by encompassing such aspects as honour and social status 
(Freedman 2007:27). According to Banda (2005:19), the definition of poverty in the context of the Ugandan youth is rooted in the failure to afford basic needs such as food, shelter, medical care, education, employment and clean water.

In the context of this study the youth will be defined as all young persons between the ages of 18 and 28, in line with the decision of the National Youth Council Statute 1993 and the 1995 Constitution of the Republic of Uganda (cf. Kibanja 2005:104).

\section{Main denominational groups in Uganda, percentage of population, church document and policy on poverty}

The list of the five main denominational groups in Uganda known by their historical and doctrinal differences and relations include the Roman Catholic Church, the Anglican Church, the Reformed-Presbyterian Church, the Baptist Church and the Pentecostal-Charismatic Church. Most of these denominations work together with Christian nongovernmental organisation (NGOs) to eradicate poverty amongst the young people in Uganda (Kamya 2004:12).

The Uganda census statistics of October 2002 (on which Frances Onyanga relies to a large extent) shows that Christians of all the denominations made up $85.2 \%$ of Uganda's population; Catholics (41.9\%) have the lead; the Anglicans (35.9\%) are nearly head-to-head; and the PentecostalCharismatic Churches (4.6\%) are in the minority. The 2002 Uganda census figures also suggest a Muslim representation of $12.1 \%$. Reformed-Presbyterians form $0.5 \%$ and Baptists $0.8 \%$. Other faiths are as elaborated above (Onyango 2002). A new census is scheduled to commence in 2013.

The author did not find any document compiled by a particular church denomination in Uganda on how to alleviate poverty amongst its poor young people, but managed to peruse through the literature gathered by the Uganda Joint Christian Council. In 2006, the Uganda Joint Christian Council (UJCC) held a routine conference committed to the witness against all forces that perpetuate poverty and to seek greater justice. The UJCC consultation on poverty and the mission of churches in Uganda on October 2006 in Kampala focused on:

TABLE 1: Religious affiliation in Uganda.

\begin{tabular}{lll}
\hline Affiliation & 1991 census & 2002 census \\
\hline Christians & $85.4 \%$ & $85.2 \%$ \\
Catholics & $44.5 \%$ & $41.9 \%$ \\
Anglicans & $39.2 \%$ & $35.9 \%$ \\
Pentecostals & - & $4.6 \%$ \\
Reformed-Presbyter & $0.1 \%$ & $0.5 \%$ \\
Baptist-Christians & $0.2 \%$ & $0.8 \%$ \\
Muslims & $10.5 \%$ & $12.1 \%$ \\
Others & $2.6 \%$ & $3.2 \%$ \\
\hline
\end{tabular}

Source: Onyango, F., 2002, '2002 Census', in Uganda Bureau of Statistics, viewed on 18 May 2012, from http://www.ubos.org/?st=pagerelations $2 \& i d=16 \& p=$ related+page
- Furthering the understanding of poverty trends and their perpetuating factors.

- Further clarifying the church's self-understanding, mission and diaconal task in the context of poverty in Uganda.

- Identifying the strategies and concrete ways for the churches to engage the challenges of poverty in Uganda.

- Empowering churches to work together in pursuit of an 'economy that serves life' (Baguma 2008:25).

A majority of the churches, if not all churches in Uganda today, do not work independently when it comes to the issue of poverty alleviation amongst the poor brethren because of a lack of available resources. They operate with a bulk of many Christian-based NGOs that are engaged in the provision of services in the areas such as health (HIV and AIDS), education, agriculture and food, income-generating activities, capacity building, water and sanitation. The predominance of Christian NGOs in this area is explained by two main factors, namely the present inability by the state to provide social and economic services to its entire population, and the poverty crisis that afflicts a large percentage of the country's population, especially the young people (Baguma 2008:28).

Major Christian International NGOs in Uganda include:

- World Vision.

- Action Against Hunger.

- Action Aid.

- Oxfam International.

- Save the Children.

- Every Child.

- Red Cross (Muranga 2004).

\section{Churches in the sphere of poverty vis-à-vis the poor}

Behind many charitable organisations in Uganda is a churchrelated or a Christian initiative. According to some of their 'paper work', the NGOs and the church diaconies are supposed to have a large portion of responsibility for local assistance. Whereas the role of some churches and NGOs are evident, others have become ambiguous with respect to the poor people. The poor people have lost the place of honour bestowed to them by the Bible and the Gospel (Mwaura 2007:94).

\section{Absent gospel in the world of the poor}

The more powerful some churches in Uganda have become, the less the poor young people are being esteemed. All sorts of things are being organised for them, but the poor themselves with their questions and contributions have been pushed to the side by these churches without any help. Hence these churches in this regard are more the 'mirror' of the poor than 'salt of the world' (Mt 5:13) (Marko 2006:54). For this reason, Maxwell (2005:217) states that these leaders have 'sinned against' the poor instead of fighting against evil. Therefore, ministers should not actually pose as advocates of the poor because they are not supportive to them. 


\section{Breakdown of justice and solidarity}

Poverty is a breakdown of justice and solidarity. In recent years, some ministers in Uganda have rediscovered their prophetic language and responsibility. They have stood up for the right of the poor, though many have not yet given a good deal of their attention to the element of justice (Barbara 2003:72). The word 'solidarity' is often heard. Unfortunalety, the reaction of some ministers are shocking, that is, they have legitimised the economic and social gap between themselves and the poor. They look at the poor as 'human refuse' for whom they have nothing to offer. They serve the poor at a distance (Barbara 2003:72). Also, due to the influence of the prosperity gospel in Uganda, some heretic pastors participate in the advancement of the culture of 'give all (money, cars and houses) and it will be given to you triple' (Lk 6:3). As a result, the unfortunate poor are left without anything, and at the end of it all such churches lose members (Amudati 1988:6). This is the method some ministers use to ignore and exploit the poor in Uganda.

\section{Church unity from the perspective of the poor}

The unity which currently exists in some churches in Uganda is between hierarchy and laity, known as the unity of authority. This does not necessarily imply social unity amongst the church members. It is an apparent unity. Sociologically speaking, these churches are in the grip of a class struggle. The idea of unity serves as a mask that covers up the efforts of the dominant class in society to maintain its position (Ebayo 2000:43). A church that claims to be one in the Lord, but is not one with those with whom the Lord has united himself, is a contradiction in terms. Hence, the church is supposed to be where the poor are and totally identify with them as does the Lord Jesus Christ (Mk 1:18, 20, 38-39; 2 Cor 8:9; Gl 3:28) (Bongo 1986:146; Simba 1998:174).

\section{Lack of faith and commitment amongst young people}

In Uganda, 95\% of the young people say that they do believe in God, though to many it is not a personal God. They only think of God in terms of being baptised in the church, married and buried by someone from the church. The majority of them do not go to church because they are marginalised, and also because they are not attuned or accustomed to the rationalisations of the theology preached which does not match their experience or their feelings or address their felt needs. Nevertheless, emancipated young people are again searching for other dimensions of Christianity (exodus from traditional churches to modern churches) at the crossroads in their lives with the parable of Jesus Christ (parable of prodigal son, Lk 15) which always takes their starting point from everyday life (Kamya 2004:18).

\section{The views of the churches with regard to poverty}

Mutebi (2003:107) says that the church is supposed to help the young people out of poverty, but some churches in
Uganda also side with oppressors. Instead of seeing poverty at a negative angle, they tend to perceive it in a positive light. They have the belief that poverty keeps the youth humble before God. The desire to develop is not a blessing, but known as a sin. The message has helped many poor young people in Uganda to accept their conditions as God-given, and their hope for a better life is projected on the world to come and not this (current) world. Therefore, the poor young men and women cease to desire and lose motivation to progress. They feel happy and worthy because theirs is the kingdom of God. According to Okidi (2000:24), the motives for this 'spiritualising' approach to poverty are obviously open to suspicion. It promotes a form of Christianity full of the 'comfortable hymn singing', which supports the status quo and carefully avoids the issues of justice and socioeconomic change.

Secondly, other churches in Uganda have a positive attitude towards material poverty. They reinforce the ideal that, besides being symbolically, culturally and materially poor, young people (Christians) must consider themselves rich. They tell their young people that they are blessed (and not cursed) by God to affirm their faith and give them dignity (Mutebi 2003:109). The Christian brethren start to confess the Word of God and prophecy that they will get blessed because they trust that God is with them and everything is part of God's purpose, and there is hope for the future. Whilst some churches in Uganda are encouraging poverty amongst their poor young people others are alleviating poverty amongst their brothers and sisters (Mutebi 2003:109).

Mutebi (2003:109) also gives a third type of teaching that is the bringing of good news to the poor in the sense of liberating them from poverty and injustice. God identifies with the poor to such an extent that to mock them is to mock him.

The fourth type is holistic, which looks the at right relationships between God and man. It stresses that the good news of the Gospel is about both spiritual and material liberation. It emphasises that the church should preach the gospel and simultaneously bring development to the community. However, too little of this is realised in the church in Uganda. Therefore the church must explore a better methodology to render poverty powerless, otherwise poverty has become disastrous amongst young people in Uganda (Mutebi 2003:112).

\section{Prosperity churches versus radical churches}

Within the Christian community in Uganda, the churches are bombarding each other concerning biblical views of wealth and poverty. Therefore, at one extreme are those who preach a prosperity gospel of 'health and wealth' for all believers. At the other extreme are radical Christians who condemn preaching about wealth and imply that it is a contradiction and unbiblical. Radical churches say that the materialistic culture is seducing the Christians into an economic lifestyle that does not glorify God, hence spiritual poverty. On the other hand, prosperity churches believe strongly that 
the Gospel for sinners must go alongside the Gospel for the materially deprived; that since our God is rich, then those who have given their lives to Jesus need not be poor (Tumusiime 1998:46).

\section{Kerby Anderson (in Stoutland 2007) asks:}

What then is the true biblical view of wealth and poverty? At first glance, the Bible seems to teach that wealth is wrong for Christians. It appears even to condemn the wealthy. After all, both Jesus Christ and the Old Testament prophets preached against materialism and seemed to say at times that true believers cannot possess wealth. (p. 2)

If this is the case, then all prosperity churches are in trouble, because they are all wrong by the New Testament standards and analogy (Tumusiime 1998:48). A comprehensive look at the relevant biblical passages reveals that a biblical view of wealth and poverty is more complex (see Anderson in Stoutland 2007:2). In fact, Scripture teaches some basic principles about wealth and condemns poverty, as we will see later. However, wealth itself is not condemned. For example, Genesis 13:2 reads that Abraham had great wealth. In Job 42:10 we see that God once again blessed Job with material possessions. In the New Testament there were rich people who followed Jesus: Joseph of Arimathea (Mt 27:57) and the socially distinguished women ministered to Jesus out of their own resources (Lk 8:3). In Deuteronomy 8 and 28; Proverbs 22:2 and Ecclesiastics 5:19 wealth is seen as evidence of God's blessing. Nevertheless, though wealth might be an evidence of God's blessing, believers should not trust in wealth, but in God (Pr 11:4; 11:28; Jr 9:23; 1 Tm 6:17; Ja 1:11; 5:2; Anderson in Stoutland 2007:2; see also Christopher 2004:74).

\section{Biblical approach in perspective of poverty}

Liberation theologians believe that when preparing sermons to be preached to the poor congregations, preachers should not only approach the Bible in a context of sin, but also from the social and material point of view (Dickson 1997:64). However, Booker (2006:99) also puts forward that a concern for care and justice is central to the Bible. It is the Gospel and the Church's mission. It is a fundamental characteristic of God and Jesus and constitutive of the church's life. Therefore, in observation of related texts below, we now take a few scriptural pericopes into consideration to see what they say with regard to the issue of poverty.

\section{Exposition of pertinent texts Exodus 3:7-10}

According to Hanneki (1998:91), Mpiyakhe and Maake (2010), both Old and the New Testaments show that God champions and cares for the poor in a very special way. When Israel was an insignificant, enslaved nation in Egypt, subject to oppression and poverty, God revealed himself to Moses in verse 8 to 'rescue' the Israelites and take them to a 'land of promise'. God has always advocated for freedom and justice for the oppressed (see also Ps 146:6-9) (Hanneki 1998:91).
The Hebrew word 'nasal' fits in this context. Primarily in the causative stem, it implies 'to snatch away'. Nasal indicates removal or liberation from all types of restrictions (Longman 1998:473). The background for the usage of nasal is in relation to God's plan to rescue the Israelites from the bondage of slavery (Ex 3:8). This expresses Yahweh's saving activity (Ex 5:23; 6:6; 18:48). It also applies to spiritual salvation from sin (Ps 39:8), destruction (Ps 22:9; 102:2), or illness (Ps 39:9) (Bromley 1979:915).

\section{Leviticus 19:9-10}

According to Goldberg (1980:101), Leviticus 19:9-10 is concerned with the social responsibility towards the poor and foreigners, and it is within the framework of the Law that God's people are called to responsibility towards the needy by feeding them (Lv 23:22; Dt 24:19-21; Rt 2:15-16; Jr $23: 2,4)$. Those who 'have' must support the 'have nots'. This shows God's love for the less privileged. It was actually one of the most specific tests of spiritual maturity - that is to care for those less fortunate. Therefore, to offer peace offerings was to claim to be at peace with God. But if the offerer did not provide for the needy, it was a hollow claim and hypocritic. Hence anyone who disobeys the commandments concerning their care is desecrating as far as God's holiness is concerned. Only those who follow his lead can achieve holiness and blessings. VanGemeren (1995:89) states that the Hebrew word 'leget' as reaping refers to the picking up of left-over produce by the poor and landless after the harvest. It is commanded in the legislation of the Pentateuch, when harvesting the field, to leave the edges of the field and the gleanings (leget) for the poor and aliens (Lv 23:22; cf. 19:9). This was intended to relieve the plight of the poor, such as widows, orphans and the resident aliens who had no land of their own.

\section{Proverbs 10:1-5}

Proverbs 10:1-5 forms the pericope of a 'diligent and lazy son'. The pericope explains that a family will thrive if the children are diligent in their work, but will collapse if they are lazy or resort to crime. The pericope emphasises the economic aspect. Since sons were responsible for the care of the parents in the old age, they could either squander the family estate if they were lazy or criminals, or build it up if they were diligent or hard-working. This section forces the young man to face the economic responsibility for the family (Mckane 1990:62). Therefore, the Hebrew word 'asel' in this portion of the Scripture implies slow, sloth, lazy. The lazy begins the day bad by hanging in the bed when he should be working ( $\operatorname{Pr} 6: 9-10 ; 26: 14)$ (VanGemeren 1995:177). The law of the Lord points to the consequences of laziness ( $\mathrm{Pr}$ 10:4). Laziness results in poverty (Pr 19:1-5). By contrast, a young man in the family of the Lord keeps bread on their table because of his diligent work (Pr 10:4; 31:27) (Douglas 2006:317).

\section{Amos 2:6-7}

The prophet Amos expressed here the new prophetic concepts of supremacy of morality. He said that the 
destiny of the people of Israel is determined by their moral behaviour and not by religious infidelity. Unethical actions, and not idolatry, will bring about the ultimate destruction of Israel. The sin for which Israel was indicted was some act of inhumanity of man. This sin was social in nature. Thus, Amos 2:6-7 tells us about the people who were filled with greed, to such an extent that they perverted justice and ruthlessly oppressed the poor and the weak. 'God had said, do not deny justice to your poor people in your law suits' (Ex 23:6-8). But the courts of law in Israel had become places for the rich and powerful to act aggressively towards the poor and take from them the little money or land they had and send them off into debt slavery and treat the poor house girls as sex slaves. But because of this, the judgement of God is to come upon them (Am 8:1-3) (Bussey 2002:12). The prophets stressed that God will surely punish those who are unjust, proud and aggressive towards the helpless, because the God who defends the poor considers it an attack on himself and profanation of his holy reputation (Bussey 2002:12).

\section{Matthew 25:34-36, 40}

Mathew 25:34-36, 40, concerns Jesus' last instruction to his disciples. He said that, in the final judgement, the standard by which the Christians will be measured is the work of compassion they had done or not done towards their poor and needy Christian brethren (Robertson 1996:274). The text is written to motivate churches to works of mercy and charity. It was often seen as an expression of love, humility and righteousness or lack of insight on the part of the unrighteous. Hence the Lord challenges us as Christians to produce good fruits by helping the disadvantaged (Mt 7:20 21) (Bloomberg 1992:377).

\section{Acts 2:42-47}

In Acts 2:42-47 rich Christians were united and they cared for the basic needs of life, not excluding the poor. They were not just Christians who worshipped the same God, but they were Christians who cared to the needs of others. They would sell their property and possessions and distribute the money amongst all according to what each needed (Ac 2:45). Luke describes the beauty of the growing and developing church; he portrays the action, dedication and devotion of early Christians in relation to God in the worship services in Jerusalem. Salvation in this community consisted of elements such as prayer, listening to the teachings of the apostles and breaking of bread. They were in one mind and heart, males and females (Karris 1988:37).

The Greek word 'Kowvos' means 'common' or 'common sharing', that is, the sharing of anything, participation, fellowship, enjoyment together is paramount. Thus it is used for the common experiences and interests of early Christians (Ac 2:42; Gl 2:9). The fellowship of believers with the Lord wrought by the Holy Spirit in the lives of the Christians is an outcome of faith, (v. 6), and joint ministration or services are rendered to the needy brethren (Ac 2:44; Rm 15:26; 2 Cor 8:4; 9:13; Heb 13:16). The furtherance of the gospel by gifts (Phlp 1:5). Louw and Nida (1989:568) also stress this sharing.

\section{James 2:14-26}

James writes of justification by works as the outward evidence of inward faith (Ja 2:20-22) which results in love and goodness (Heb 10:24) (Barclay 1995:78). The Greek word 'Eprov' which denotes work, deeds or action is relevant to this text. The idea of work is stressed in Romans 15:18. It frequently occurs in an ethical sense of human actions; good or bad (Mt 3:3; 26:10; Jn 3:20-21; Rm 2:7-15; 1 Th 1:3) (Louw \& Nida 1988:217). In James 2:14 the fact that God does work in an inner transformation underscores James's concern over those who claim to have faith, but whose lives are not marked by appropriate actions. He says such kind of faith is both useless and dead (vv. 20, 26), for the regenerated person will have a new heart that will express itself in what he or she says and does. All in all, Christians must love and care for those in need to affirm their faith (Mt 12:33-37), otherwise their faith is in vain without good works (Vines 1996:153).

\section{A proposed method to break down the relentless poverty NGOs and government's contribution to poverty mitigation}

Whilst government should not have to shoulder the entire responsibility for caring for young people, it must take seriously the statements in Amos, Exodus and Leviticus about fighting injustice, oppression, and care for the poor (see Anderson in Stoutland 2007:4). Anderson (in Stoutland 2007) argues that:

government must not shirk its God-given responsibility to defend the poor from injustice [and oppression]. If government will not do this, or if the oppression [and injustice] is coming from the government itself, then ... [young people] must exercise their prophetic voice and speak out against governmental abuse and misuse of their power [and position]. (p. 4)

Government must first establish the laws and statutes that prohibit and punish injustice. These laws should not just be introduced but have significant penalties and be rigorously enforced so that the youth are not exploited and defrauded (see Anderson in Stoutland 2007:4). Therefore, we also need a welfare system from government and NGOs that emphasise work, and initiatives which do not foster a dependency syndrome and laziness amongst the poor young people:

One of the things integral to the Old and New Testament system and missing in our modern system of welfare is a means test. If [young] people have true needs, we should help them. But when they are lazy and have poor work habits, we should admonish them to improve. (Anderson in Stoutland 2007:4)

Thus, in Uganda the current welfare system continues poverty by not identifying those who have legitimate genuine need and those who are abusing the system.

\section{The responsibility of the church in community development}

The community development of the church should entail that the ministers come together with Christians to exchange ideas. The aim of the development of the poor communities 
should first of all be spiritual. It should be spiritual enterprises in which the church must motivate its actions towards the poor young people in such a way that they will come to know Lord Jesus, his grace and his love (Maxwell 2005:256). Community development of the church should not only benefit the youth spiritually, but also in the socio-economic and psychological spheres. Development should be meant to trigger transformation processes. Transformation must be aimed at the psychological liberation from the trap of poverty in which the poor young people are caught up. Thus, as it proceeds, it should help the poor to discover a goal in life for which they can work and strive (Marko 2006:62).

\section{Prophetic preaching in a context of poverty}

When ministers approach the Biblical text with a view of interpreting it for preaching in the context of poverty, their theological orientation should be such that they respond to their exegesis interpretation within the crisis of the prevailing situation of poverty. The content of preaching has to be the living Word of God, Jesus Christ and his promises based on the evangelical truth of his salvific deeds (Dickson 1997:83). The prophetic preaching in the church of the poor should tell them that God has not deserted them, he is on their side and he will deliver them from the causes of poverty and from the situation of their poverty. It must inspire, motivate and drive them to open up new vistas, a vision and a hope to ameliorate their situation and thus to collaborate in God's work of liberation (Dickson 1997:84).

\section{Churches' solidarity with the poor}

The ministers need to identify with the youth and the community in the context of poverty. They do not just need to live in that community; they also need to listen and to observe. Pastoral closeness to the young people is very important. It helps one to be attentive of the youth's positive and negative stories, their views of life, God, the church, government and other people. By being with them in their distress, taking their side, supporting them pastorally and showing them God's love, one starts gaining their trust and acquiring existential knowledge of that situation (Bongo 1986:185).

\section{The holiness of the church from the perspective of the poor}

The holiness of the church is the reflection of the unique holiness of God himself. When we say that God is holy, we actually mean his love (1 Jn 4:16). Thus, his love is holy, free and sublime or inspirational. God loves the poor, not because they are part of his creation, but because there is no one who cares about them. It is God's holy love which the church must bring forth in Christ to reflect his holiness on earth and to invite the poor to it; then the church will become a space where this holy love can be enjoyed, celebrated and shared. Both sinners and beggars alike must be pointed to this love of spiritual and emotional healing (Christiano 1997:158).

\section{The church as koinonia}

The church should rediscover its prophetic gifts in the area of generosity as the first face and erase the middle-class character of the church. The existing communities of the rich and the poor must overthrow the existing order (1 Cor $1: 28)$ and establish a new community that should be based on the socio-economic freedom of the poor. The early church practiced koinonia in its original state - a mutual community in which people stood by each other in all affairs of life (Ac 2:42-45). In both the Old and New Testaments this feeling of generosity was strong. Therefore, the church must rebuild its relationship with the poor young people so as to stop its broken covenant with God (Carl 2005:107).

\section{The youth as agents of change}

The poor youths themselves must also set the pace, seeking and discovering God as the one who not only stands at their side, but who also gives them back their stolen humanity, dignity, wealth, status and honour (Tumusiime 1998:48). The Christian youths are called not just in the hope of a better life to come, but to transform the present world here and now so that all youths, equal in their human dignity, may have fullness of life according to God's will for them (Tumusiime 1998:48). Kamya's (2004) message to the youth in Uganda is:

you need not wait for God to destroy this world and then create a new world, but to cooperate with God to transform this present world and make it new by being creative and innovative. (p. 27)

\section{Conclusion}

The church's task is to uphold justice and care for the needy, and denounce all kinds of evil: greed and injustice. Poverty is a structural sin, not a personal fault of an individual. Structures have to be changed by all stakeholders: government, the church and the rich. The church has many opportunities of making its witnesses in changing this situation. Above all, it must advocate for the need for change and help young people to see the meaning of responsible actions in the search for new methods and a new pattern of living (Dickson 1997:68). Churches need to encourage poverty alleviation and to debunk or remove all theologies which glorify poverty, which expect the poor young people to resign themselves to their wretched condition. Churches should not only spread the good news, but also combat poverty. This is because preaching the Gospel to sinners and caring for the needy are both the components of church mission and salvation history (Opio 2008:72).

\section{Acknowledgements}

My thanks and gratitude to all the following who made this article possible: My Lord and Saviour Jesus Christ without whom I can do nothing, the only contant caretaker in less caring world. My promoter, Prof. Dr Rantoa Letsosa for his patience, guidance and support. A true example of a shepherd. Rochelle Flint who tirelessly reviewed and edited my article. To all my friends for their gifts of friendship.

\section{Competing interests}

The authors declare that they have no financial or personal relationship(s) that may have inappropriately influenced them in writing this article. 


\section{Authors' contributions}

A.W. (North-West University), was the project leader and wrote the article. R.L. (North-West University) edited, restructured and finalised the article for submission.

\section{References}

Amudati, R., 1988, Religion, individualism, and persistence of Capitalism, Bryan and Sons Press Ltd., Kampala.

Baguma, K.G., 2008, 'Uganda Joint Christian Council, an annual report for 2006 Political, social and economic context of the project', The Journal on Uganda Joint Christian Council 16(4), 24-32.

Bada, L., 2004, Biblical view of poverty and wealth: The government must not shirk its God-given duty to defend the poor, Fountain Publication, Kampala.

Banda, F., 2005, Factors affecting development: Urban and rural young people in Uganda, Kisubi Printing Press, Entebbe.

Barbara, R., 2003, No peace without justice: The task of churches in community development in Uganda, River Blue Publication, Kampala.

Barclay, W. 1995, The daily study Bible, Saint Andrew Press, Edinburg.

Bloomberg, L.C., 1992, The new American commentary: An exegetical and theological exposition of Holy Scripture, Broad Man Press, Nashville, TN.

Bongo, M., 1986, Christian unity and social reconciliation, Fountain Publication, Kampala.

Booker, S., 2006, Church's partnership with the State, Booker House Publication, n.p., MI.

Bromley, G.W., 1999, International Standard Bible commentary, Eerdmans Publishing Company, Grand Rapids, MI.

Bussey, K.M., 2002, The message of Amos; a commentary for today's church, Abingdon, Oxon

Carl, T.F., 2005, Churches' response to favoritism and division, Route De Ferney, Geneva.

Christiano, M., 1997, Caring for poor people is living for Christ, Woodward Press, Geneva.

Christopher, E., 2004, Strategy for effective church growth: Role of leadership for effective ministry, Oxford University Press, Oxford.

Dickson, S.B., 1997, Preaching and poverty: Contextualization, Christian Publication Ltd., Kampala.

Douglas, K.S., 2006, The new American commentary: An exegetical theological exposition of Holy Scripture, Intervarsity Press, Downers Grove, IL.

Ebayo, M., 2000, Church mission and justice, Orbit Book Publishers, Kampala.

Freedman, L., 2007, 'Rural livelihoods and poverty reduction strategies: Four African countries', Journal of Development Studies 40(4), 1-30.

Goldberg, L., 1980, Leviticus: A study guide commentary, Zondervan House, Grand Rapids, MI.
Hanneki, P., 1998, Biblical principles for churches in Africa, Christian Action Centre, Entebbe.

Kamya, O.B., 2004, Reflection on the church and poverty in Uganda: Make poverty a history, Entebbe Book Shop Publication, Entebbe.

Karris, J., 1988, A commentary on the Acts of the Apostles, Double Day, Garden City, NY.

Kibanja, G.M., 2005, Understanding and reducing persistent poverty among the youth in Uganda, Fountain Publishers, Kampala.

Longman, T., 1998, Dictionary of Biblical imagery, Intervarsity Press, Downers Grove, IL.

Louw, J.P. \& Nida, E.A., 1988, Greek-English lexicon of the New Testament based on the semantic domains, United Bible Societies, New York, NY.

Louw, J.P. \& Nida, E.A., 1989, Greek-English lexicon of the New Testament based on the semantic domains, United Bible Societies, New York, NY.

Maxwell, B., 2005, Theology beyond mere survival: From poverty to abundant life, Christian Press, Entebbe.

Marko, P., 2006, Towards a church in solidarity with the poor, Fountain Publishers, Kampala.

Mckane, W., 1990, Proverbs: A new approach, SCM Press Ltd., London.

Mpiyakhe, J.K. \& Maake, J.M., 2010, 'The impact and effects of trauma resulting from excommunication', HTS Teologies Studies/Theological Studies 66(1), 13 pages. http://dx.doi.org/10.4102/hts.v66i1.803

Mutebi, P., 2003, Churches and social development, Social Work Centre, Kampala.

Mwaura, P., 2007, Integrity of churches and NGOs in Uganda in light of the Gospel, Fountain Publication, Kampala.

Muranga, F., 2004, Nutrition Education and Policy: A Partnership between the University of Wisconsin-Madison and Makerere University, Uganda, viewed 10th May 2012, from http://www.cals.wisc. Edu/uganda/NGOs.htm!

Okidi, P., 2000, Local pastors' link to fight poverty, Christians Today Publication, Kampala.

Onyango, F., 2002, '2002 Census', in Uganda Bureau of Statistics, viewed on 18 May 2012, from http://www.ubos.org/?st=pagerelations2\&id=16\&p=related+page.

Opio, E., 2008, Poverty eradication among poor people: a divine mandate, Fountain Publication, Kampala.

Robertson, H.G., 1996, A survey of the New Testament, Zondervan Publishing House, Grand Rapids, MI.

Simba, A.J., 1998, 'The end of liberal dream', Christianity and Crisis 41(4), 172-186.

Stoutland, F., 2007, 'Christianity and poverty', in For Ordinary Christians.org, viewed 07 February 2014 from http://www.forordinarychristians.org/Docs/F GCl Christianity\%20and\%20Poverty.pdf

Tumusiime, K., 1998, Basic challenges to the church in Uganda: Poverty and wealth, Orbit Book Shop Press, Kampala.

VanGemeren W.A., 1995, Dictionary of the Old Testament theology and exegesis, Zondervan Publishing House, Grand Rapids, MI.

Vines, E., 1996, An expository dictionary of Old Testament and New Testament words, Fleming Company, Old Tappan, NJ. 